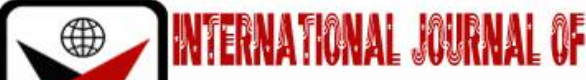

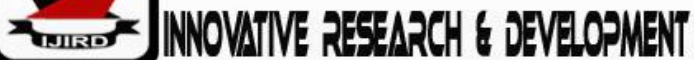

ISSN 2278-0211 (Online)

\section{Determinants of Income Diversification Strategies among Smallholder Cashew Nut Farmers in Nigeria}

\author{
Motunrayo Helen Falaye \\ Lecturer, Department of Economics and Management Studies, \\ Afe Babalola University, Ado-Ekiti, Nigeria \\ Sylvester Oluwadare 0jo \\ Professor, Department of Economics and Management Studies, \\ Afe Babalola University, Ado-Ekiti, Nigeria
}

\begin{abstract}
:
The study examined the determinants of income diversification strategies among cashew nut farmers in Kogi State, Nigeria. It determined the socio-economic characteristics, status of income diversification and factors influencing income diversification among the cashew nut farmers. A multi-stage sampling procedure was used to select 150 respondents for the study. Primary data were collected with the aid of structured questionnaire. Descriptive statistics, diversification index, mean of income share approach and Tobit regression model were employed to analyse the data. The results revealed that the farmers were literate with 73.4 percent having secondary school education and above. They had small holding farm with over 80\% cropping between 1-5 hectares and with average farm size of 3.7 hectares. The farmers were involved in different income sources with civil service jobs, arable crop farming and livestock farming were the major farming system used by the farmers. The determinants of income diversification in the study area were education, household size, income, extension visit and extension contact and these variables were positively related to income diversification. The study concluded that, the respondents in the study area adopted multiple income generating activities with only 6.7 percent of the farmers had income generating of one (1) were civil service remained the dominant income source for the respondents. Socio- economic characteristics of the respondents were positively and significantly related meaning that as socio-economic characteristic increases the income diversification of the respondents' increases. Therefore based on the findings the following are recommended; training of farmers to improve their knowledge should be encourage, provision of credit facilities, extension agents trainings should be made available to the farmers since it has significant effect for the farmers in creating different livelihood activities.
\end{abstract}

Keywords: Smallholder farmers, Income Diversification, Income share, Tobit model

\section{Introduction}

Agriculture continues to dominate the economy, contributing about 42\% of Gross Domestic Product (GDP) and accounts for about 77\% of employment (Agricultural Transformation Agenda, 2015). Agriculture is an essential sector for majority of the rural populations' livelihood in developing countries, Nigeria inclusive. It has been the predominant activity for most rural households in Sub-Saharan Africa (SSA) which offers a strong option for spurring growth, overcoming poverty, and enhancing food security (World Bank, 2008).

The changing socioeconomic, political, environmental and climatic atmosphere in Nigeria and other developing countries such as, increased incidence of poverty, political instability, climate change and variability have continued to aggravate the living conditions of most households especially those living in the rural areas. The accompanying increase in food insecurity levels has led residents of these economies to devise a number of strategies such as income diversification and community self-help to cushion the negative effects of these changes.

Diversification refers to the expansion of the range of rural activities outside the farm and is seen as a dynamic adaptation process created through pressures and opportunities

(Ellis, 2000). The farm household expands its activities in order to increase farm income or to reduce income variability by exploiting new or existing market or non-market opportunities, including waged employment in the local nonfarm sector and the exploitation of natural resources (FAO and World Bank, 2001).

According to Asogwa (2008), cashew is an emerging commodity crop whose cultivation cuts across the seven agro-ecologies in Nigeria. In each of the 27 cashew producing states in Nigeria the numerical strength of the farmers is increasing, while the crops hectarage is correspondingly on the increase. Cashew is a crop with wide ecological distribution within Nigeria. It is a tree crop of considerable economic importance to Nigeria and other tropical countries. Major cashew growing areas in Nigeria are by order of importance. Enugu, Abia, Imo, Anambra, Ebonyi and Cross River States in the Eastern part of the country; Oyo, Osun, Ondo, Ekiti and Ogun States in the Western part as well as Kwara, kogi, 
Nasarawa, Benue, Taraba, Niger and FCT in the Middle Belt and also Sokoto and Kebbi States in the North West (Ezeagu, 2002).

Rural households in developing countries have for a long time been perceived as farm households, and that they receive their income predominantly from agriculture. Evidence abounds, however, that rural households do not only receive a significant proportion of their incomes from non-farm sources, but also it is a significant source of employment for rural folks. Haggblade (2010) reports that rural nonfarm activities constitute a significant proportion of rural employment and income from this source accounts for 35 to50 percent of total rural household income across the developing world.

\section{Methodology}

\subsection{Study Area}

The study was conducted in Kogi State. The state is located in the middle belt region of Nigeria. Kogi State is in the Southern guinea savannah of the vegetation zones and most centrally located of all Nigerian State. The state has distinct wet and dry seasons. The raining season fall between April and October while the dry season is between November and March (Kogi ADP, 2003). Majority of the people in the state are small scale farmers and are rich in diversified soil condition which enables agriculture to thrive in the state. The main tribes are the Igala, Ebira and Yoruba. The crops commonly cultivated include; Cashew, Palm tree, Coffee, Groundnut, Maize, Cassava, Rice, yam and Melon.

\subsection{Data Collection}

Primary data were used for this study. Data were collected with the aid of a set of well-structured questionnaire. Information were collected on: (a) households' socio-economic characteristics such as age, gender, educational level, farm size, farm income, non-farm income, extension contact, membership of association, household size, amount of credit received, number of income sources, (b) pattern and determinants of income diversification

\subsection{Analytical Technique}

To achieve the objectives of the study, descriptive statistics such as mean, frequency tables and percentages were used to describe the socio-economic characteristics of the respondents in the study area. In addition, Tobit regression model was used to examine the factors responsible for income diversification.

\subsection{Mean of Income Share Approach}

Mean of income shares approach was used to estimate the income shares obtained by the cashew nut farmers in the study area. This approach estimates the shares of incomes of individual farmers by finding the shares of each income source in the sum of total cashew nut farmers' income (TCFI) (Davis et al., 2007). The general mean of income shares formula is given as;

$\mathrm{MS}_{=} \sum \mathrm{n}_{\mathrm{h}}=1$ yih $/ \mathrm{Yh}$

Where;

$\mathrm{i}=$ The income source

$\mathrm{Y}=$ Total Income

$\mathrm{y}=$ income from particular activity

$\mathrm{h}=$ the cashew nut farmer

$\mathrm{n}=$ number of cashew farmers

The sum of total cashew farmers' income (TCFI) is given as:

$\mathrm{TCFI}=\sum_{\mathrm{j}}=\mathbf{1} \mathbf{Y j}$

Where:

TCFI= Total cashew farmers income coming from all sources $j$,

$\mathrm{J}=1,2,3,4 \ldots .$. Farm and non-farm income

\subsection{Diversification Index}

Diversification index was used to measure income diversity; it takes care of both the number of sources of income and balance among them. The Diversity index is expressed as;

Diversity Index =

$\sum$ rij

$\underline{\mathrm{r}}$

Where:

$\mathrm{r}_{\mathrm{i}}=$ number of activities engaged in by an individual

$\sum \mathrm{ri}=$ Total number of activities identified

$\mathrm{j}=$ No of respondents

$\mathrm{i}=1,2,-----n$ income sources

If there is a lack of diversity, the index is unity. So, the degree of diversification depends on the amount by which diversity index exceeds unity. 


\subsection{Tobit Regression Model}

The Tobit model was used to achieve the general objective of the study.

The model is specified as:

$\mathrm{Y}_{\mathrm{i}}=\mathrm{X}_{\mathrm{i}} \mathrm{b}$ if $\mathrm{i}^{*}=\mathrm{X}_{\mathrm{i}} \mathrm{b}+\mathrm{u}_{\mathrm{i}}>\mathrm{T}_{\mathrm{i}}$

Where:

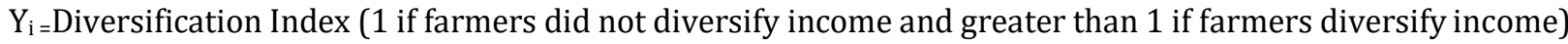

$\mathrm{X}_{\mathrm{i}}=$ Vector of exogenous explanatory variables

$\mathrm{X}_{1}=$ Age of household head (Years)

$\mathrm{X}_{2}=$ Sex of household head (Male $=1$, Female $=0$ )

$\mathrm{X}_{3}=$ Education (Years of formal schooling)

$\mathrm{X}_{4}=$ Household size (Number)

$\mathrm{X}_{5}=$ Farm size (Hectares)

$\mathrm{X}_{6}=$ Farming experience (Years)

$\mathrm{X}_{7}=$ Membership of cooperative (Yes $=1$, otherwise $=0$ )

$\mathrm{X}_{8}=$ Extension contact (Number of contacts)

$\mathrm{X}_{9}=$ Income from Children $(\mathrm{N})$

$\mathrm{X}_{10}=$ Labour source (Both family and Hired labour $=1$, otherwise $=0$ )

$\mathrm{X}_{11}=$ Total income of the respondents $(\mathrm{N})$

$\mathrm{X}_{12}=$ Distance to nearest market (kilometre)

$\mathrm{X}_{13}=$ Marital Status (Married=1, otherwise $=0$ )

$\mathrm{X}_{14}=$ Cashew Revenue

$\varepsilon=$ Error Term

\section{Results and Discussion}

This section describes the results of the socio-economic characteristics assessment for the farmers because of their perceived impact on income diversification, these are; gender, age, household size, farm size, years of farming experience, educational level, membership of cooperative, extension contact, access to credit and marital status.

The gender distribution of the cashew farmers is presented in Table 1. The result reveals that, majority 71.3 percent of the respondents in the study area were males and $28.7 \%$ of the respondents were females. The result shows that cashew nut productions are mostly practised by male farmers compared to females. This may be due to high energy involvement. This result is similar to the result obtained by Oluwatayo (2009). In his study on poverty and income diversification among households in rural Nigeria, he noted that majority of his respondents were males that engaged in different livelihood activities in his study area. He further argued that there are more male -headed household than female-headed households.

The result for ages of the respondents shows that, 3.4 percent of the farmers were below 30 years, $22.2 \%$ were within $30-40$ years, $32.7 \%$ were within $41-50$ years, $27.9 \%$ were within $51-60$ years, $11.5 \%$ were within $61-70$ years and $2.7 \%$ were above 70 years

The mean age of farmers was 48.8 years, and this shows that the cashew nut farmers in the study area are still in their active years. Age is associated with skills enhancement (experience), accumulation of resources and extensive social capital that ought to contribute positively to well-being (Bashaasha et al., 2006). Minot and Epprecht (2006) noted that age may be associated with skills, more experience and remunerative non-farm activities while maintaining food production for own consumption.

The marital status of the cashew farmers indicated that majority $80.7 \%$ of cashew farmers were married, $8.0 \%$ were single and $11.3 \%$ were widower. This implies that cashew production in the state is mostly practiced by married people who perhaps used the proceeds from the cashew farming to augment family income and compliment family food supply. It is expected that family labor would be more available where the household heads are married (Amaza et al., 2009). Marital status may influence the size of households as married farmers may have larger household sizes which may increase consumption expenditure thereby making them more prone to food insecurity.

The result of the educational status of the respondents shows that $8.7 \%$ of the respondents had no formal education, $18.0 \%$ of the respondents had primary education and $44.7 \%$ had a secondary school education and $28.7 \%$ of the respondents had tertiary education. The study further revealed that farmers in the study area were literate. Education increases the ability of farmers to use their resources efficiently, also education enhances farmers' ability to obtain analyze and interpret agricultural information.

The result for the household size of the respondents shows that, $36.8 \%$ have $1-5$ members, $61.3 \%$ have $6-12$ members. A mean family size of 6 members was obtained among the sampled respondents. This implies that household size of cashew farmers in the area could be one of the necessary conditions for engaging in cashew production, as large family size could ease the labor constraint, the area cultivated to different crop enterprises, the amount of farm produce retained for domestic consumption, and the marketable surplus are all determined by size of the farm household (Amaza et al., 2009). The result obtained is similar to the result obtained by Oluwatayo (2010) and Babatunde et al., (2007).

Respondents' distribution by their farming experienced shows that 34.6 percent had between 1-10 years of farming experience, $54.0 \%$ had between $11-20$ years and $10.6 \%$ had between $21-30$ years and only $0.7 \%$ had farming experience greater than 30 years. Average farming experience was 14.9 years farming experience is expected to influence income diversification because the accumulation of skills over time by older farmers can make them combine different income-generating activities which in turn improve their income level. Farming experience is an important factor 
determining both the productivity and the production level in farming activities. But the effect of farming experience on productivity and production may be positive or negative. Generally, it would appear that up to a certain number of years, farming experience would have a positive effect; after that, the effect may become negative. The negative effect may be derived from aging or reluctance to change from old and familiar farm practices and techniques to those that are modern (Amaza et al., 2006).

The results for farm size revealed that 11.3 percent had farm size less than 1 hectare. $68.6 \%$ had between $1-5$ hectares and 20.1\% had between 6-10 hectares. Average farm size is 3.7 hectares. From the results, majority of the farmers in the study area had an average farm sizes and also, limited farm sizes may encourage the farmers to diversify into non-farm activities.

\begin{tabular}{|c|c|c|}
\hline Variable & Frequency & Percentage (\%) \\
\hline \multicolumn{3}{|l|}{ Gender } \\
\hline Male & 107 & 71.3 \\
\hline Female & 43 & 28.7 \\
\hline Total & 150 & 100 \\
\hline \multicolumn{3}{|l|}{ Age (Years) } \\
\hline Less than 30 & 5 & 3.4 \\
\hline $30-40$ & 33 & 22.2 \\
\hline $41-50$ & 49 & 32.7 \\
\hline $51-60$ & 42 & 27.9 \\
\hline $61-70$ & 17 & 11.5 \\
\hline Above 70 & 4 & 2.7 \\
\hline Total & 150 & 100 \\
\hline \multicolumn{3}{|l|}{ Marital status } \\
\hline Single & 12 & 8.0 \\
\hline Married & 121 & 80.7 \\
\hline Widower & 17 & 11.3 \\
\hline Total & 150 & 100 \\
\hline \multicolumn{3}{|l|}{ Educational status } \\
\hline No formal education & 13 & 8.7 \\
\hline Primary education & 27 & 18.0 \\
\hline Secondary education & 67 & 44.7 \\
\hline Tertiary education & 43 & 28.7 \\
\hline Total & 150 & 100 \\
\hline \multicolumn{3}{|l|}{ Household size (years) } \\
\hline $1-5$ & 55 & 36.8 \\
\hline $6-12$ & 92 & 61.3 \\
\hline Above 13 & 3 & 2.1 \\
\hline Total & 150 & 100 \\
\hline \multicolumn{3}{|l|}{ Farming experience (years) } \\
\hline $1-10$ & 52 & 34.6 \\
\hline $11-20$ & 81 & 54.0 \\
\hline $21-30$ & 16 & 10.6 \\
\hline Above 30 & 1 & 0.7 \\
\hline Total & 150 & 100 \\
\hline \multicolumn{3}{|l|}{ Farm size (ha) } \\
\hline$<1$ & 17 & 11.3 \\
\hline $1-5$ & 103 & 68.6 \\
\hline $6-10$ & 30 & 20.1 \\
\hline Total & 150 & 100 \\
\hline
\end{tabular}

Table 1: Socio-Economic and Farm Characteristics of the Respondents Source: Field Survey.2017

\subsection{Farmers' Sources of Income}

The result in table 2 shows the distribution of farmers based on their different income sources. It was found that $11.4 \%$ derived their income from livestock keeping, $13.0 \%$ from arable cropping, and $3.26 \%$ from agricultural wage job. $15.89 \%$ obtained income from civil service, $16.29 \%$ from trading, $8.35 \%$ from Artisan, $1.83 \%$ from labour wage, $2.24 \%$ from driving business, $2.65 \%$ from Okada business, $10.59 \%$ from Rental services, $6.52 \%$ from gifts, $4.48 \%$ from sales of property and $3.46 \%$ from timber production. This result implies that majority of the cashew nut farmers in Kogi State diversify more in to civil service which accounted for more than $47 \%$ of the total income share of all the farmers diversify activities in the study area. These, thus implies the cashew nut farmers in the study area are civil servants and vice versa. 


\begin{tabular}{|c|c|c|c|c|}
\hline Sources of Income & $\begin{array}{c}\text { Number of } \\
\text { Farmers }\end{array}$ & $\begin{array}{c}\text { Percentage of } \\
\text { Farmers (\%) }\end{array}$ & $\begin{array}{c}\text { Average } \\
\text { Income (N) }\end{array}$ & $\begin{array}{c}\text { Income Share In } \\
\text { Total Income(N) }\end{array}$ \\
\hline Farm Income & & & & 2.00 \\
\hline Livestock & 56 & 37.3 & 1144 & 6.27 \\
\hline Arable cropping & 64 & 42.7 & 34773 & 0.59 \\
\hline Agric labour & 16 & 10.7 & 3286.7 & 47.86 \\
\hline Non-farm income & & & 265470 & 18.02 \\
\hline Civil service & 78 & 52.0 & 99947 & 8.69 \\
\hline Trading & 80 & 53.3 & 48220 & 0.59 \\
\hline Artisan & 41 & 27.3 & 3273.3 & 0.59 \\
\hline Labour wage & 9 & 6.0 & 21333 & 3.41 \\
\hline Driving business & 11 & 7.3 & 78333.3 & 3.02 \\
\hline 'Okada' business & 13 & 8.7 & 16750 & 0.68 \\
\hline Rent (house) & 52 & 34.7 & 3746.7 & 3.60 \\
\hline Gifts & 32 & 21.3 & 19987 & 3.40 \\
\hline Sales of property & 22 & 14.7 & & 100 \\
\hline (land) & 17 & 11.3 & 554630.7 & \\
\hline Timber business & 491 & & & \\
\hline Total & & & & \\
\hline
\end{tabular}

Table 2: Distribution of Farmers According to Their Income Sources

*Multiple Responses Were Allowed, Hence Total Frequency Exceeded Sample Size

\subsection{Farmers Degree of Income Diversification}

The result in Table 3 shows the degree of income diversification among the farmers in the study area. Respondents with the most diversified income sources had the largest additional income generating activity combinations of (3) three, 6.7 percent of the respondents had just one additional income generating activity; this implies that these farmers did not diversify their income sources at all. A total of 34 farmers had income generating activities of 2 accounting for $22.7,31.3 \%$ had 3 , and $22.0 \%$ had 4 , while $13.3 \%$ had an income activity combination of $5,2.0 \%$ had a combination of 6 and the same number is applicable for 7 also. The mean activities combinations are 3.27. This implies that an average respondent in the study area had its members involved in at least three (3) income generating activities at a time in the study area. These activities are distributed across two sectors, that is the farm and the non-farm sectors due to long list of activities identified in the study area.

\begin{tabular}{|c|c|c|}
\hline Number of Activities & Frequencies & Percentage (\%) \\
\hline 1 & 10 & 6.7 \\
\hline 2 & 34 & 22.7 \\
\hline 3 & 47 & 31.3 \\
\hline 4 & 33 & 22.0 \\
\hline 5 & 20 & 13.3 \\
\hline 6 & 3 & 2.0 \\
\hline 7 & 3 & 2.0 \\
\hline Total & 150 & 100 \\
\hline
\end{tabular}

Table 3: Distribution of Respondents by their Degree of Income Diversification Source: Field study, 2017

\subsection{Determinants of Income Diversification among The Respondents}

The factors that determine income diversification are presented in table 4 . The result shows that the coefficient obtained for education was negative and significant at 5\% level of probability. This result implies that each additional year of schooling decreased income diversification by (-0.0052). This indicated that the higher the level of education of the respondents the lower their tendencies to diversify into additional income generating activities since they have a stable source of income from white collar job.

The coefficient obtained for household size was positive and significant at $5 \%$. This implies that an increase in household size would increase income diversification. A unit Increase in household size will leads to (0.0114) increase in income diversification. This implies that household head with larger family size will perhaps diversify their income to be able to argument family income and compliment family food supply.

The income from children is strongly significant and positively determined income diversification. This implies that as farmers income increases their level of income diversification into other additional income generating activities increases.

The coefficient obtained for extension visit was positive and significant at $5 \%$ level. The implication of this is that increase in the number of extension visits would increase income diversification; frequent visit of extension agents can provide information to the respondents on better and modern techniques of farming as well as income- generating activities. 
The result for extension contact was strongly significant and negatively related to income diversification. This implies as the number of extension contacts increases with the respondents the level of income diversification decreases that is, $1 \%$ increase in extension contact will lead to -0.0897 decrease in income diversification. The farmers tend to stick to a crop they have adequate knowledge about than diversifying into an unknown crop or business they can't guarantee its outcome.

Cashew revenue was negatively correlated with income diversification as the cashew revenue of the respondents increases their level of diversification decreased, this is not farfetched because has the farmers revenue from cashew increases, they we be relatively satisfied with their income and may not necessarily diversify.

Marital status was negatively correlated with income diversification, while farming experience was also negatively correlated with income diversification, has the farming experience of the farmers increases their level of income diversification decreased by (-0.0012).

Income from children had a negative relationship with income diversification, a unit increase in income from children will leads to $(-0.000000026)$ decreased in income diversification.

Labour source was negatively related with income diversification, a unit increase in labour source will lead to (-0.0099) decreased in income diversification.

Distance to market had a positive relationship with income diversification. A unit increase in the market distance will leads to (0.0008) increased in the income diversification. The farmers will tend to diversify into another enterprise, since the cashew market is far away from them.

Based on the findings of this study, the hypothesis which states that there is no significant relationship between income diversification and socio-economic characteristics of the farmers was rejected while the alternative hypothesis which states that there is significant relationship between income diversification and socio- economic characteristics of farmers was accepted.

\begin{tabular}{|c|c|c|c|c|}
\hline Variable & Coefficient & Standard Error & t- ratio & $\mathbf{p}>|\mathbf{t}|$ \\
\hline Gender & 0.0306 & 0.0177 & 1.73 & 0.086 \\
\hline Cashew revenue & $-3.84 \times 10^{-08}$ & $6.37 \times 10^{-08}$ & -0.60 & 0.548 \\
\hline Age & 0.0002 & 0.0012 & 0.15 & 0.878 \\
\hline Marital status & 0.0103 & 0.0204 & -0.60 & 0.616 \\
\hline Education & -0.0052 & 0.0021 & $-2.51^{* *}$ & 0.442 \\
\hline $\begin{array}{c}\text { Farming } \\
\text { experience }\end{array}$ & -0.0012 & 0.0016 & -0.77 & 0.898 \\
\hline Farm size & 0.0008 & 0.0051 & 0.13 & 0.005 \\
\hline Household Size & 0.0114 & 0.0040 & $2.84^{* *}$ & 0.324 \\
\hline $\begin{array}{c}\text { Income from } \\
\text { children }\end{array}$ & $-2.60 \times 10^{-08}$ & $2.26 \times 10^{-07}$ & -0.11 & 0.675 \\
\hline $\begin{array}{c}\text { Labour source } \\
\text { Membership of } \\
\text { cooperative }\end{array}$ & -0.0099 & 0.0091 & -0.99 & 0.002 \\
\hline Total Income & -0.0033 & 0.0079 & -0.42 & 0.679 \\
\hline Distance to market & 0.0008 & & & 0.013 \\
\hline Extension visit & 0.0341 & $2.49 \times 10^{-08}$ & $3.12^{* * *}$ & 0.020 \\
\hline Extension contact & -0.0897 & 0.0019 & 0.42 & 0.004 \\
\hline Constant & 0.1741 & 0.0381 & $-2.36^{*}$ & $2.91^{* * *}$ \\
\hline Sigma & 0.0870186 & 0.0050488 & & \\
\hline
\end{tabular}

Table 4: Determinants of Income Diversification among the Respondents

$$
\begin{gathered}
* * *=\text { Significant at } 1 \% \quad * *=\text { Significant at } 5 \% \\
*=\text { Significant at } 10 \%
\end{gathered}
$$

\section{Conclusion}

Empirically, income diversification in Kogi State, Nigeria was high. Only 6.7 percent of the farmers had income generating activity of 1 , indicating that the respondents adopted multiple income generating-activities. However, civil service remained the dominant income source for the respondents. Socio-economic characteristics such as education, household size, income, extension visit and extension contacts were the main determinants of income diversification, meaning that adequate attention should be given to these variables. Income diversification and socio- economic characteristics of the respondents were positively and significantly related meaning that as socio- economic characteristics increases the income diversification of the respondent increases.

It is also recommended that since income level of households has a positive relationship with diversification of livelihood options, so as to improve life of farming households, Therefore, efforts need to be continued in more aggressive manner on training of farmers to improve their knowledge and traditional experiences to improve their per capital income. 


\section{References}

i. Amaza, B., Eze C., and Eze V. (2009). Factors Influencing the Use of Fertilizer in Arable Crop Production among Smallholder Farmers in Owerri Agricultural Zone of Imo State. Academia Arena; 2(6), Pp 90-96.

ii. Asogwa A.U, Hammed L.A. and Ndubuaku T.C.N (2008).Integrated Production and Protection Practices of Cashew in Nigeria. African Journal of Biotechnology Vol.7 (25), 4868-4873.

iii. Davis, D. (2007).The Determinants and Impacts of Income Diversification in Rural Ethiopia: The Case of Communities in Southern Nations, Nationalities, and Peoples Regional State unpublished MSc Thesis, Graduate School of Economics, and Addis Ababa University, Ethiopia.

iv. Ellis, F. 2000. Rural Livelihoods and Diversity in Developing Countries. Oxford University Press.

v. Ezeagu (2002). Assessment of the situation and Development Prospects for Cashew Nut Sector: A report on Nigerian Export Promotion Council, Abuja Nigeria Vol. (13): pp. 1-37.

vi. Haggblade, S. (2005). The Rural Non-Agricultural Economy: Pathway out of Poverty or Pathway in? Paper Presented at the Meeting of the International Food Policy Research Institute on the Future of Small-Farms, Washington D.Cindex.htm January 24th, 2010.

vii. Oluwatayo, I. B. (2009). Poverty and Income Diversification among Households in Rural Nigeria: A Gender Analysis of Livelihood Patterns. Paper Presented at the 2nd Instituto de EstudosSociais de Economicos (IESE). Conference Number 41 on Dynamics of Poverty and Patterns of Economic Accumulation, April 22-23, 2009, Maputo, Mozambique.

viii. Workshop 'Cashew Production Technology', March 26-29, Cocoa Research Institute of World Bank (2008).World Development Report 2008: Agriculture for Development Washington, DC.

ix. World Bank www.data.worldbank.org/indicator/AG.CON.FERT.ZS/countries 